International Journal of Heritage, Tourism and Hospitality Vol. (11), No. (4), October, 2017

By: Faculty of Tourism and Hotels, Fayoum University

A Special Issue on 'Entrepreneurship of Tourism, Hospitality and Heritage in Egypt': A Vision for Sustainable Development'

The $1^{\text {st }}$ International Conference Organized by Faculty of Tourism and Hotel Management, Pharos University, Alexandria, Egypt on $24^{\text {th }}-27^{\text {th }}$ October 2017

\title{
The Influence of Hotels' Green Activities on Customers' Ethical Behavior: The Case of Five-star Hotels in Alexandria
}

Shimaa Abo Elsoad Mohamed Soliman

Abstract

Higher Institute of Tourism \& Hotel Management, El Seyouf, Alex., Egypt

Due to the rising ecological consciousness in the hospitality industry, green hotel seems to be growing niche in the competitive lodging industry and the number of consumers who are interested to stay at green hotel has also increased. In addition, the impact of the hotel industry on the environment is quite large because it is an economic sector undergoing rapid growth. The hotels consume lots of water, energy, and unrecyclable products that in the end endanger the environment. A typical hotel can emit daily or yearly between 160 and $200 \mathrm{~kg} / \mathrm{m} 2$ per room per floor of carbon dioxide (co2). It is conceivable that ecological awareness can influence on consumer behavior. Lately, consumers have become more possible to express their environmental consciousness by purchasing environmentally friendly products and services.

Therefore, This study examine to what extent the hotels apply green activities, particularly in Alexandria-Egypt; to identify the relationship between ethics conducts for consumers and hotel green activities; to explore the most effect demographics factors on customers'ethical behavior; to discover the degree up to which potential consumers intend to stay at green hotel, boycott or act discursively against un ethical hotels; and finally to look into the relation between customers' attitude and their actual behaviors towards green hotel. In order to achieve these objectives, (10100) web-based, on-site questionnaires and manually forms were randomly distributed to five-star hotels' consumers in Alexandria governorate -Egypt. The returned and valid questionnaires were (1080) questionnaires $(98,2 \%)$. The checklist was another method applied to reveal the least applied green activities among hotels and to support the result of the questionnaire. Data were described using mean, standard deviation, Pearson coefficient correlation, Spearman coefficient linear regression. The study highlighted that there is a positive significant relationship between hotel green activities and ethical consumer behavior. In addition, hoteliers did not take the advantage of the ethical consumer behavior of growing opportunities. Although, hoteliers applied certain activities, they ignored the role of engaging customers in green activities and announcing the environmental efforts for the community, which appeared stagnation of ethical consumer behavior.

Keywords: Ethical consumer behavior, Green hotel, Ethical consumption, Boycotting, discursive actions against unethical hotel.

\section{Introduction}

Tourism has been distinguished as the sum of the relations arising out of activities of personnel traveling to and staying in places outside their usual environment for not more than one consecutive year for leisure time, business and other purposes (McCabe, 2009). A tourist destination is considered a complex and open system that, as a whole, establishes an offer capable of attracting tourists in the long term. In this context, a tourism destination is collected of complex networks with a large number of resources and co-producing actors delivering a diversity of products and services (Díaz and Rodríguez, 2016). Tourism is an industry that very much depends on the nature environment (Gursoy, 2018).

Hotels shape a major component of the tourism industry. From its operational actions that require lighting, heating, cooling, cleaning, and washing, to the provision of supplementary service such as restaurant, entertainment, and retailing. The hotel industry bears characteristics that can impact any social environmental order throughout its demand on energy, water, food supply and waste disposal. If not probably managed, hotels can adversely affect the 
environment (Ofori, Savage and Lin-heng, 2010). The hotel industry is under the force to meet the growing demand for sustainable goods and services while working to remedy its impact on the environment, society and the economy (Manhas, 2012). Due to the rising ecological consciousness in the hospitality industry, the green hotel seems to be growing niche in the competitive lodging industry and the number of consumers who are interested to stay in a green hotel has also increased (Quoquab, Thurasamy, and Mohammad, 2018).

Keynote (2002) argued that green and ethical criteria are beginning to play a greater role in purchasing patterns. In addition, Harrison Harrison, Newholm and Shaw(2005) added that there is a "niche" market of ethical consumers. Ethical consumer behaviors are quite a complex and wide-ranging group of phenomena. Goodwin and Francis, 2003; Manaktola and Jauhari, 2007; Han, Hsu, and Sheu, 2010) assured that there is a number of lodging consumers that search for hotels, which follow eco-friendly activities.

Cialdini (2009) suggested that consumers see the firm as being effortful in being green, they will be more motivated to do their part. This is because effort on the part of the firm triggers a sense of responsibility on the part of the consumer. Wagner, Richard and Barton (2009) found that consumers will join in more actual green behavior when they perceive a firm to be greener and these perceptions will be affected by cues of the company environmental efforts. When the firm makes a request to a consumer to conserve, the presence of other cues suggesting that the firm is also doing so should increase consumer perception of the company greenness and influence consumer saving.

Consequently, despite the fact that ethical consumers are no longer classified as edge (Carrington, Neville and Whitwell, 2014), and ethical products and services now account for rising shares of many diverse markets (Ethical Consumer Markets Report, 2012). Barber (2012) pointed out that from an administrative point, it has also been claimed that managers in the hospitality sector should be paying attention to consider ethical consumption, avoid unethical activities, develop ethical strategies; therefore they could place their companies uniquely in the increasingly competitive accommodation market (Bohdanowiz,2005; Manaktola and Jaurhari, 2007; Han et al., 2011). Tilikidou et al. (2013) discussed that consumer intention to stay at a green hotel is much higher than any actions towards actually staying. Juvan \&Dolcinar(2014) added that the behavior intention doesn't necessarily translate into actual behavior and the connection between the two concepts is quite a week, resulting in a distinct attitude-behavior in consumer behavior. Wang et al. (2015) summarized that consumer conservation behavior is affected by the extent to which consumer realize the company as being green.

Despite customers are increasingly choosing an environmentally friendly hotel, moreover, applying green activities will be the choice criterion for guests, not all hotels carry out environmental activities. In addition, hoteliers don't accommodate changes to their organizational activities thus, don't encourage favorable ethical behavior among their guests as energy conservation behavior. A significant amount of literature is found about green hotel activities; however, less importance has been given to its influence on ethical consumer behavior. Therefore, this study focuses on the interaction between hotel green activities and ethical actions among customers. This structure is projected to present a clear direction to the researchers and hoteliers about the most significant issues of ethical consumer behavior towards green activities in hotels. The study addresses objectives as follows; to inspect to what extent the hotels apply green activities, particularly in Alexandria-Egypt, to examine the interaction between ethics conducts for customers and hotel green activities; to explore the most effect demographics factors on ethical consumer's behavior; to discover the rate of customer intention to stay in a green hotel, boycott or act discursively against unethical hotels; 
and to look into the relation between customers' attitude and their actual behaviors towards a green hotel.

\section{Relevant Literature \\ The impact of hotel on the environment}

According to Kirk (1996); Webster (2000), unplanned and uncontrolled hotel expansion can critically generate gross ecological degradation. While arguably hotels do not deplete huge amounts of ecological resources on an individual basis, collectively they cause significant impacts on the natural environment. Keller (1996) argued that it was notable in large hotel complexes in expanding and newly industrialized countries; there was a need to evade a waste of resources and pollution in the hotel business. The hotel business, which consumed fewer and was less polluting than traditional smokestack industries, nerveless, affected the surroundings through its water and energy needs and its solid and liquid wastes. Many hotels were equipped with refrigeration and air-conditioning units which could include substances damaging to the ozone layer. The impact of the hotel industry on the environment was quite large because it was an economic sector undergoing rapid growth.

Forte (2003) mentioned that because of these environmental problems the need of green hotel is rising day by day and they are becoming the heart of the tourism industry. The tourist and hotels' consumers are more anxious for environmental problems and have ongoing to consider the green hotel and environment- friendly hotel in their lodging choice. Bohdanowicz (2005) pointed out that the accommodation industry (hotels -hostels-and so on) consumes a huge quantity of energy and uses of fossil fuel rather than renewable energy, thus means that hotel emits pollution gases that directly affect global warming. A typical hotel can emit between 160 and $200 \mathrm{~kg} / \mathrm{m} 2$ per room per floor of carbon dioxide (co2), and some European hotels as much as 13.6 mega tones of $\mathrm{co}^{2}$ also anticipated that one kilogram of waste per guest per day is created by the average hotel. Miththapala (2011) estimated that the power costs constitute 18 percent of the total operational costs of the hotel. Barberán et al. (2013) added that it has also found that water consumption per visitor in a hotel can be around three times that of a person stays at home. Ali and Frew (2013) estimated that energy consumption per bed per night in hotels around 130 megajoules, with the hotel emitting an average of 20.6 kilograms of carbon dioxide per night and using more energy per visitor than local society due to different energy facilities such as pools and gym.Chen, Sloan and Legrand (2009) pointed out that consumers' activities have influenced the earth's ecology system for many thousands of years. Nowadays, the negative consequences of human conducts can be observed everywhere. Being one of the larger in industries in the world, the hospitality industry is an important provider to these troubles. Han et al. (2011) added that lodging industry is one of the chief industries that create environmental problems. The industry uses lots of water, energy, and unrecyclable products that in the end endanger the environment, therefore, some hotels eager to attract potential consumers, especially consumers who have eco-friendly intention towards hotels that run in green way. Furthermore, Lefevre (2012) mentioned that hotel's impact comes chiefly from the energy, water, food and other resources that are consumed during operating the hotel by the solid and liquid wastes it produces. Carayannis (2013) demonstrated that there is the need for the hotel sector, is the desire of tourists to pay a premium for sustainable management activities and the extra bonus of increased occupancy rate.

According to Rahman, Reynolds, and Svaren, (2012), competitiveness in terms of obtainable green can enhance profitability in the long run by lowering operating cost and return the saving to the consumers. Moreover, being green adds value to the image of hotels and resorts in the marketplace. It is also critical that, Zemake (2014) pointed out that the hospitality industry 
includes lodging, restaurant, event planning, theme parks, transportation, cruise line and other fields within the tourism industry; Wickramasinghe (2016) reported that the increasing number of traveler arrivals so, already increasing the amounts of energy and water consumption while generating higher amounts of waste. Considering both the economic and green factors, it is thus important that hotels carry out investments inefficient energy and water management activities and effective waste management.

\section{The concept of green hotel}

The term "green hotel" characterizes a hotel that strives being more environmentally friendly through the effective consumption of energy, water, and resources while provides high quality services. Green hotel conserves by saving water, reducing energy use, and reducing solid waste (Alexander \& Kennedy, 2002).Supplementary, Zhou (2011) declared that with gradual improvement of ecological consciousness, green consumption has become the choice of the most citizens in many countries. The green hotel can offer consumers a good natural room through the indoor and outdoor green environment. The green hotel also provides consumers with healthy service and enjoyment. Zengeni, Zengeni and Muzambi, (2013) stated that the term of green hotel is the same as the term of environmentally friendly hotel, eco-friendly hotel, and sustainable hotel. Furthermore, Han and Yoon (2015) added that there is no doubt that sustainability has become a critical issue within the global lodging industry.

\section{Green hotel activities}

Pearce (1994) pointed out that green consumption intends to keep up basic needs and pursue a better quality of life. Green Hotelier (2003) pointed out that the Red Sea Sustainable Tourism Initiative (RSSTI), set up in 1999, is one of the first tourism programmes in the Middle East and Africa to embrace the principles of sustainable development. The RSSTI is "a Tourism Development Authority (TDA)-performed programme with financial support provided by the US Agency for International Development (USAID) and technical assistance from the international firm PA Consulting Group". The TDA is also supporting the implementation of Environmental Management Systems (EMS) in resorts, eight resorts have implemented a resort-wide environmental management system (EMS) which resulted in significant savings. Two resorts so far, Steigenberger Golf Resort and The Oberoi Sahl Hasheesh have been awarded Green Globe certification and others have been awarded certificates of excellence by the Ministry of Tourism. Holcomb, Upchurch and Okumus (2007) stated that Marriott is one of the largest hotel chains with 3100 units in the US and 66 units in other countries. It is the primary hotel to work together with Conservation International. Marriott has five key CSR (Corporate social responsibility) initiatives focusing on waste reduction, supply chain management, green buildings, and water and energy conservation. Attila (2016) mentioned that more than a hundred hotels won the label of green hotel in Hungary in the past twenty years, these hotels are found in areas to contribute to enhancement of the competitiveness in the particular destinations.

Weeden( 2002) argued that an ethical hotel strategy contains ecological protection together with truthful pricing, fair behavior of the locally owned companies, fair treatment and wages for all employees, honest promotion techniques etc. Green Hotels Association (2005) identified a green hotel that takes measures to harm the environment less or even more to keep the physical environment by efficient use of energy, water and other materials. Wenger (2008) observed that greening activities become the near-to-absolute solutions to hotel industry in modern times. He stated that rapid development in the hotel industry often goes hand-in-hand with the lack of waste disposal infrastructure. 


\section{Best energy activities}

The best energy activities in the hotels industry include many aspects.Regarding refrigerator and airconditioning, Lubbe (2003) argued that a number of refrigerant contains chlorofluorocarbons (CFCs) and hydrochlorfluorocarbons (HCFCs), both of which contributes to damage in the ozone layer surrounding the earth and hence to global warming. Thing of all that the air-conditioning units, deep freezers, mini bars and ice maker machines which needed, these posted a challenge in hotels to develop alternative methods of cooling that are not hazard to environment. Hansen and Brown (2003) provided an important indicator that present two written schedules; a maintenance schedule and a preventive maintenance schedule for every piece of equipment in the facility. If these schedules are in use, risk levels will be reduced. Green Lodging News (2008) referred that the Holiday Inn in North Vancouver, British Columbia has saved approximately USD $\$ 16,000$ annually and reduced 28 percent of its energy consumption through installing an in room energy management system. The system features occupancy sensors that automatically monitor and adjust individual room temperatures. The system was able to ensure a return on investment within 14 months.

Ironically, William and Frye (2009) explained that guests' rooms hot water should not exceed (120) degrees. The National Swimming Pool Institute suggested that swimming pools should never exceed (80) degree. Exceeding these recommended peak temperatures poses a safety threat while incurring over and unwanted energy cost. Graci and Dodds( 2009) stated that hotels have started to reduce water, energy and waste. The Fairmont Dallas Hotel, United States has installed tinted windows and digital thermostats in their guest rooms to minimize the consumption of energy resulting in $\$ 50,000$ savings in electricity costs yearly. Ellis (2010) summarized that reduction effort in energy consumption is one of the best greening activities. Maltzman and Shirley (2011) indicated that carbon foot print and sustainability are two important terms in the green wave. Carbon footprint made up of two components a direct part and the other indirect. The direct part includes such things as the output of homes heating, ventilation, and air conditioning (HVAC) system. The indirect part includes items like the energy takes to deliver the things bought. It is also important because it can somewhat mitigated or at least reduced by actively reducing energy consumption.

\section{Hotels water conservation}

Smith, Choy, Chong and Verma (2015) mentioned that one of the most popular ways that hotels have adapted to reduce water consuming is replacing current devices with water-efficient ones, including laundry facilities, toilets, showers and faucets. It was showed that setting up low-flow shower heads and aerated faucets saved 1.50 per room per month for one hotel and using the water efficient toilets saved to the same hotel 180.000 gallons of water per year. A more recent study by Quintana, and Canino (2017) referred that RIU's hotels conducts (is a Spanish hotel chain founded by the Riu family as a small holiday firm) have focused essentially on water saving, the reuse of water and garden water management. Environmental protection measures as saving water in hotel room achieved, through the efficient use of toilets (water tank quantity decreasing and the proper dual discharge mechanisms, as well as encouraging consumer to save water by placing informative leaflet in the room to save water.

\section{Community action}

Regarding consumer involvement, Dub, Enz, Renaghan and Siguaw (1999), showed that the colony hotel seasonal resort in Kennebunkport, Marine, is the only supporter to actively involve consumers in its "green" hotel by combining activities and education. Bardi (2010) 
referred that the consumer's desire to take part in these initiatives saves the hotel thousands of liters of water, cleaning products and energy per day. The same procedure can be used to limit the amount of fresh towels required, e.g. only if they are on the floor, they get exchanged. Furthermore, Baker, Davis and Weaver (2014) added that consumers want to know that they can really make a difference, and firms should dedicate great attention to adequately inform consumers on how to join in. Han and Yoon (2015) pointed out that it is particularly important for businesses in the accommodation sector, where a dynamic involvement of consumer is crucial. Smith (2015) asserted that although hotels sustainability efforts are crucial for saving energy and resources, a key element of any green activities is consumers' reaction and participation. Shanti (2016) focused on that the Orchid hotel, for example, is equipped with a green button in each room, which permits the consumer to choose an eco-friendly room stay vis-à-vis electricity consumption in the room. The use of a simple green button has been vastly successful

\section{Waste reduction and recycling}

Whilst, $46 \%$ of a hotel's solid waste is food waste and since the food waste composes, hotels are more and more recognizing that composting is a better alternative to dumping food waste, as composed waste is used as organic fertilizers (Alexander and Kennedy, 2002). Some firms still focus on reduction and replacement strategies; the reduced use of resources by means of efficiency and replacement of damaging substances with less harmful ones. These include using fewer resources and reduced amount of energy, replacing materials with recycled stock, and committing to the concept of zero net waste (Townsend, 2009).

Maltzman and Shirley (2011) emphasized that food waste is already used as an alternative energy source. One source is from fast food and other restaurants that generate grease from the food preparation process, like cooking burger. The UK seems a leading this effort. Thorne et al. (2011) revealed that many firms join in recycling programs, the reuse of materials, especially steel, aluminum paper, glass, rubber and some plastics for reuse. In fact, recycling is one of the country's greatest sustainability success stories. Swami (2011) demonstrated that paper and stationery is an area where cost saving is made. Purchasing policy has also been used to improve a hotel's environmental performance. Suppliers should be requested to use recyclable products, and offer environmentally preferred products wherever possible.

\section{Ethical consumer behavior}

Since it is becoming something of global standard, we will stick with the label ' green consumer ' even through' green consumer ' would be a more accurate reflection of the a variety of activities that consumption entails, and less of a contradiction in terms. Similarly green purchasing would be a more suitable description of their activities than green consumption (Pattie, 1995). Ecological awareness can influence on consumer behavior; lately, consumers have become more possible to express their environmental consciousness by purchasing environmentally friendly products and services (Follows and Jobber, 2000; Makeower, 2009; do Paço \& Raposo, 2009; Fisher, Bashyal and Bachman, 2012).

Ethical and green consumerism is defined as any decision based on consumption choices due to personal morals, beliefs and values (Crane and Matten, 2004). Consumers express their awareness about the ethical and environmental behavior of businesses through ethical buying and green buying (De Pelsmacker, Driesen and Rayp, 2005). Firat and Dholakia (2003) focused on nevertheless; comparatively less interest has been placed on ethics in the consumer side of marketing exchange, however, such factor is essential, because "understanding ourselves as persons who consume may clarify much of what we are about as human beings, since, 
consumption is much of our life". Devinney, Auger and Eckhardt (2010) stated that the concept of ethical consumer has evolved over the last twenty -five or more years from an approximately restricted focus on the ecology issues to a concept that incorporates matters of conscious more broadly, only to return to its green roots with the recent interest about climate change.

Bhate and Lawler (1997) described that ethical consumer commonly buy and use environmentally friendly goods. However, Diamantopoulos, Schlegelmilch, Sinkovics and Bohlen (2003) suggested that ethical consumer not only purchase green products but also recycle, join in pro-environmental political conduct, and display high levels of environmental knowledge. Carrier and Luetchford (2012) discused that the moral principles that concern ethical consumers are different widely. The decision to start consuming ethically can show a desire to become a part of social movement and it can bring better household or a better world. Carrier and Luetchford (2012) further proved that ethics acting a vital role in human activities, in general, and consumption, in a particular. Many recent studies have called for research into this field .Although there is indication that many consumers are increasingly attracted by offers which are socially and environmentally responsible, even recently, little is known about the motives that drive some consumers toward or deter others from, higher levels of ethical awareness and action in their buying decisions. Tilikidou and Delistavrou, (2011); Boemi et al. (2013) reported that with reference to the study efforts in Greece, a few studies are stated that there have been some verification that Greeks' intentions to take part in future boycotts of unethical hotels were rather high Delistavrou and Tilikidou (2014) further proved that with revere to hotel sector, ethical consumption might include a) choice of a green and/or ethical hotel, b) boycotting a hotel which has been found "guilty" about unethical activities towards the natural and the human environment, as well as c) discursive public communication about the above mentioned issues.

Regarding to understanding ethical consumer behavior, Brinkmann, (2003) referred that consumer can take on a number of often subtle forms.

- Positive purchasing means preferring ethical commodities.

- Negative purchasing means avoiding products disapproved.

- Company-based purchasing means targeting a company as a whole.

- The fully screened approach that means looking at companies and products together and evaluating which brand are the most ethical.

Tallontire, Rentsendorj and Bowfield (2001) proposed three types of ethical consumerism namely positive, negative and consumer action. The later form has been afterwards named "discursive" by Micheletti, Stolle, Nishikawa and Wright (2005). The positive type concerns the choice of ethical products or service (e.g. eco-efficient products, organics, green hotels etc). The negative type concerns the boycotting or consumers' remit from particular products, certain firms or groups of firms; more generally it means actions of denial or exit from a certain market. The discursive type refers to a channel of communication among consumers, to the formulation of public opinion through a framework of social debate, as well as to a number of continuously transforming cultural activities, which are based mainly on computer and network innovations Weeden (2002). In other words, the ethical consumption activity includes positive choice behaviors such as the purchase of fairly traded or environmentally friendly products, and can involve avoidance and boycott of certain goods or companies (Cherrier, 2007; Newholm and Shaw 2007).

Boycotting describes the act of choosing and buying certain products and services over others, due to social considerations (Ozcaglar-Toulouse, Shiu, and Shaw, 2006; Shaw and Clarke, 
1999; Shaw and Shiu, 2002, 2003). Schwartz (2017) showed that the most common form of such expression is deliberately avoiding (i.e. boycotting) products and companies with ethically subject practices. On the other hand, Harrison etal.(2005) found that boycotting and participation in anti-consumption events; consumers may also express their social concerns by avoiding certain actions or by not purchasing a product. Companies that commercialize certain products may have an unethical social record (company-oriented boycotting) or because their products are unsustainable (product oriented boycotting. Schwartz (2017) referred that boycotting also has a converse practice called "boycotting " which consumers deliberately seek products and companies whose business practices they consider ethically exemplary .

Shaw and Newholm,(2002) ensured that voluntary simplicity or ethical simplifiers; ethical simplifiers are consumers that select to reduce their overall consumption levels and to adopt a simpler lifestyle due to social and ecological considerations. With regard to sustainable consumer activities; ethical consumer behavior also refers to post- purchase and other behaviors associated to how products are used, recycling and waste management which done by ethically minded consumers (Gronhoj, 2006) and the activity of BYOB to reduce plastic bag use (Cherrier, 2006). This class refers to singular behaviors, as opposed to the previous category which refers to an overall lifestyle. Lewis and Potter (2013) concluded that ethical consumption is a reasonably new phenomena, it can clearly be associated to range of longer term strives around consumer politics. Here, boycott is seen as some of the earliest of political consumerism. Weeden, and Boluk (2014) investigated that today's ethical consumerism primarily takes the form of supporting particular merchants.

\section{Hypotheses}

The dependent variable is the ethical consumer behavior where the independent variable is hotel green activities. Based on the previously cited theoretical, the following hypotheses indicating to:

Hypothesis 1: The implementing of green activities in five -star hotels in Alexandria - Egypt is limited.

Hypothesis 2: There is a significant correlation between hotels' green activities and customers' ethical behavior.

Hypothesis 3: There is a gap between consumers' attitudes and their actual behaviors' towards green hotel.

Hypothesis 4: There is a significant correlation between the demographic characteristics of customers and their ethical behaviors.

\section{Research methods}

After discussing previous review relevant to the problem of the study, the theoretical study is complemented by field study. The present study is descriptive because it is applied through an orderly method for gathering and analysis of data. The study is also attempted to find out facts, as believed by Monette, Sullivan and DeJong (2011). In the current study, the quantitative and semiquantitative methods are developed. Quantitative research is designed to examine to what extent hotels apply green activities, particularly in Alexandria-Egypt and to identify the relationship between ethics conducts for customers and hotel green activities. Furthermore, the questionnaire is used to get information that can't be easily observed or be already on hand in written or computerized form, as well as, to investigate the effect of hotel green activities on Customers' Ethical consumer's behavior and to test hypotheses of the current study. The checklist is a semi-quantitative method. The checklist is a familiar method in many disciplines and is 
characterized by collecting data systematically and this procedure has been precious for evaluating the different management tool as reported by Botero et al.(2018). In this study, the checklist applied to support the result of the questionnaire. The study is mainly carried in basic phases as described in figure (1). Moreover, it can be seen that the deductive method is applied since; a deductive approach is dealt with developing hypotheses based on existing theory, then designing a research strategy to test the hypothesis. In addition, the study was based on views of respondents to make recommendations and conclusions.

Figure 1: Study design diagram

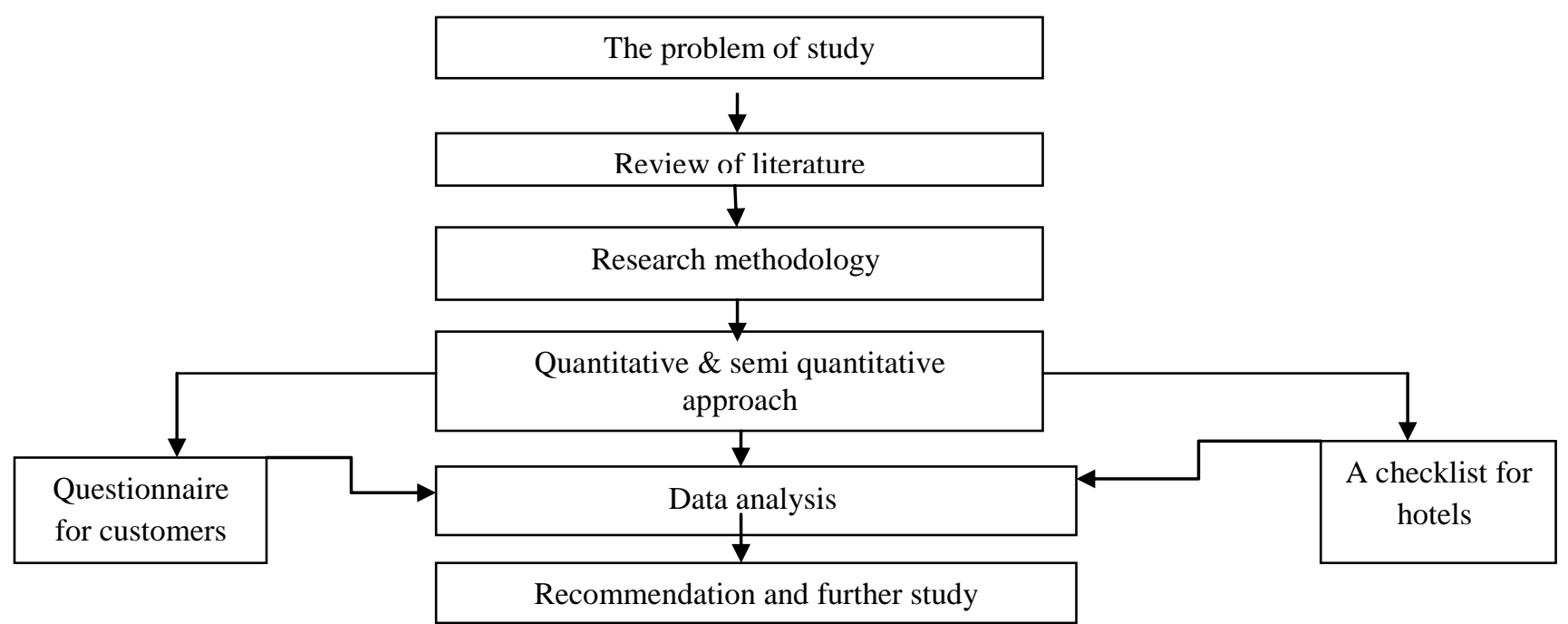

The population of the study

Source: Researcher, 2018

The study is targeted five-star hotels' customers' in Alexandria Governorate. Alexandria has been selected because it is one of the governorates of Egypt located in the northern part of the country, directly on the Mediterranean Sea, making it one of the most important tourist destinations in Egypt. The main reason for choosing five-star hotels that they are very wellgroomed and set very high standards and they offer superior service. Moreover, five-star hotels usually face stronger national and international competition. According to The Egyptian Hotel Guide (EHA, 2017), the number of five-star hotels in Alex was eight as follows:

1-Four Seasons Hotel Alexandria

2-Helnan Palestine Hotel

3-Hilton Alexandria Green Plaza Hotel

4-Hilton Alexandria Corniche Hotel

5-Iberotel Borg El Arab Hotel

6-Mediterranean Azure Hotel

7-Sheraton Montaza Hotel

8-Hilton Alexandria King's Ranch

Because of, there were a limited number of five-star hotels in Alexandria. It was possible to collect data from whole population community as it is of a manageable size (eight hotels). In this study, data were collected within 6 months (from June 2017 until December 2018).

\section{Research instrument}

According to Ly (2013), the questionnaire is the most productive tool to collect information that represents the general opinions of the target group. It is widely used by many studies due to its high suitability and time-efficiency, therefore, the questionnaire was used to collect data for the 
current study. The questionnaire was distributed online and by hand to five- star hotels' customer's in Alexandria. It was distributed 1100 forms. Only 1080 forms were returned with a percentage of $98.2 \%$. The questionnaire was consisted of (29) questions and separated into three sections.

Firstly, respondents were asked to answer five demographical questions about gender, age category, nationality, lifestyle and the level of education. Section two was designed to evaluate the independent variable ( hotels' green activities). Section two is developed by adapting factors from Millar and Baloglu (2008), which respondents were asked to rate their assessment for green activities on twelve factors. These factors included: using low-flow toilets, toilets flappers, shower heads and faucet; using compact fluorescent or other efficient bulbs; hotel has a socially responsible; existing posters showing hotel environmental policy; existing leaflets for guests to save energy in hotel rooms; existing of recycling boxes in guests rooms; using some environmental slogans and advertising environmental actions to customers; there are areas for smokers separated from non-smokers; towels and linens are washed according to guest opinion; heating ventilating and air-conditioning system is implemented efficiently to ensure making indoor environmental quality, and the hotel is successful in its environmental

In the third section, participants were asked about how often, if at all, they have done each of the environmental activities. This section consists of twelve factors as follows; campaigning about an environmental or social issue; feeling favorable attitude toward organic food; the willing to stay in a green hotel; recommending a hotel because of its environmental efforts; switching to other hotel for ecological reason; paying more for environmentally friendly hotel when there were a cheaper alternatives; using recycling boxes; using an automatic key card system to save room energy ; using recyclable products; engaging in boycotting towards unethical hotel, avoiding a hotel because of its safety and hygiene scandals and finally participating in the protest event against unethical hotel. Ethical customers' behaviors (positive-negative - customers' actions) were investigated also measured on a 3-point Likert type scale form $1=$ Haven't done, $2=$ Done at least once, $3=$ Done $5+$ times. The ethical customers' behavior scale resembles the scale adopted from Han et al. (2010).

It was essential to check if data obtained from the questionnaire reflect the reality of green activities among five-star hotels in Alexandria,so data also are collected through the checklist method. The checklist is conducted by the researcher through objective questions having 2 ranges of answers: Yes or No. According to William et al. (1977), in case of objective questions, it seems rational to anticipate that the usual methods of truth assignments and logic apply since it was supposed that the researcher is a good researcher and is therefore logical. The checklist was designed as a list of questions about hotels' green activities which adopted from the study done by Bohdanowicz (2006), Mensah(2006), and Tzschentke, kirk, and Lynch (2008). The checklist was used to measure green activities among hotels upon five main indicators; there are environmental policy and management, water reduction, waste reduction and recycling, pollution control and energy reduction. Each main factor consisted of three subquestions. Environmental policy and management included A1-does the hotel provide all employees with the training and resources required to meet green objectives; A2-are there leaflets which show the hotel environmental policy?; A3-is environmental label existed on hotels products? ; water reduction includes B1-does the hotel use a linen reuse program in guests' rooms?; B2-does the hotel use low flow toilets, showerheads, and faucets?; B3-does the hotel use automatic faucets or toilets in public restrooms?

Waste reduction and recycling included: $\mathrm{C} 1$ - are recycling bins for glass, plastic, and paper provided in all guest rooms or public area; C2- does the hotel use food waste monitoring system?; C3- are there a a variety of fruits, herbs, and vegetables grown in the hotel to serve 
the healthiest; Pollution control included :D1-are environmentally High-efficiency Particulate Air (HEPA) filters used?, D2-are housekeeping environmentally products used in the hotel?; D3- are there non-smoking rooms and smoking rooms?. Energy reduction measures included three questions are as follows; E1-does the hotel use on-site renewable energy?; E2-does the hotel install daylight and occupancy sensors for low occupancy areas?; E3-does the hotel use high efficient bulbs to save energy?

\section{Sampling}

A simple random sample was conducted by Statistics is a software package (SPSS) program. Firstly, it was opened data analysis icon, a select case had been pressed, followed by a random sample of cases icon was chosen; then entered the required sample (1080) and pressed on continue then OK, finally page appeared random numbers for the required sample. 1080 forms were valid with response rate $(98,2 \%)$. The sample size was calculated using PASS program version 13 at $80 \%$ power and $95 \%$ confidence level (5\% error margin) to ensure the precision of the results obtained so, it was evidence that results are near to the actual reality.

\section{Limitations of the study}

The result of the study incorporated some of the limitations. These limitations include the negligence of the effect of cultural level of customers on ethical behavior and absence some demographics characteristics among customers so, it was very difficult to compare research results with the previous studies, in addition, the negligence of identifying motivations methods among customers which helps in raising ethical behavior in the community.

\section{Validity and reliability of the study}

Regarding questionnaire, forms were displayed to a panel of five of experts judges including three hotel professors and two hotels' managers out of the core sample. The experts were asked to enhance scale items; to improve its clarity and readability. The questionnaire was modified on the basis of comments and suggestions of arbitrators. The stability of forms was supported by reapplication randomly on a sample of customers(ten customers), as suggested by El Kadhi (2009). It was calculated a coefficient correlation between the first application and the second; it was $(88 \%)$ and this coefficient correlation was statistically significant at (0.01), which indicated the stability of forms and usability of the application, Cronbach's $\alpha$ (alpha) reliability test has been used. The score of alpha reliability was 0.893 , this indicates that there is good alpha reliability, and this correlation is significant $\mathrm{P}<0.001$.

Table 1 : Reliability scale statistics for questionnaire

\begin{tabular}{|l|l|l|}
\hline Variable & No. of sub-variables & Cronbach's Alpha \\
\hline 1- Hotels' green activities & 12 & 0.742 \\
\hline 2- Customers' ethical consumer's behavior & 12 & 0.878 \\
\hline Overall & 24 & 0.893 \\
\hline
\end{tabular}

Correlation is significant at $\mathrm{P}<0.001$

On the other part, checklist questions were chosen upon the examination done by assistant managers in the hotel field and reformulation of some questions to ensure the validity of the checklist. Cronbach's $\alpha$ (alpha) reliability test has been used to refine the instrument. Questions that brought down the internal reliability, had been removed. The score of alpha reliability was (0.881) as shown in table (2).

Table 2: Reliability Statistics for the checklist 
International Journal of Heritage, Tourism and Hospitality Vol. (11), No. (4), October, 2017

By: Faculty of Tourism and Hotels, Fayoum University

A Special Issue on 'Entrepreneurship of Tourism, Hospitality and Heritage in Egypt': A Vision for Sustainable Development'

The $1^{\text {st }}$ International Conference Organized by Faculty of Tourism and Hotel Management, Pharos University,

Alexandria, Egypt on $24^{\text {th }}-27^{\text {th }}$ October 2017

\begin{tabular}{|l|l|l|}
\hline Variable & No. of Items & Cronbach's Alpha \\
\hline Environmental policy and management & 3 & 0.845 \\
\hline Measures for water reduction & 3 & 0.781 \\
\hline Waste reduction and recycling & 3 & 0.810 \\
\hline Pollution control & 3 & 0.944 \\
\hline Measures to adopt energy reduction & 3 & 0.865 \\
\hline Overall environmental activities factors & 15 & 0.881 \\
\hline
\end{tabular}

Correlation is significant at $\mathrm{P}<0.001$

\section{Data analysis}

The SPSS (Statistical Package for the Social Sciences) version 20.0 was employed to calculate descriptive statistics as declared by Kirkpatrick (2013) Firstly, it was used Cronbach's $\alpha$ (alpha) reliability test to ensure the accuracy of the study. Data were described using mean, standard deviation. Pearson coefficient correlation was used to correlate between two normally distributed quantitative variables (to find the relation between hotels' green activities and customers' ethical behavior). Spearman coefficient was used to correlate between two distributed ordinal variables and finally, it was used linear regression to detect the most independent factor among green activities affecting customers' ethical behavior. Interpretation and discussion of results are provided along with results.

\section{Results and discussion}

This section interprets the results of different techniques and methods used to obtain the data and describe the findings in light of the study problem being investigated.

Table 3: Demographic profile for respondents $(n=1080)$

\begin{tabular}{|l|c|c|}
\hline Variable & Number & Percentage \\
\hline Gender & 692 & 64.1 \\
\hline Female & 388 & 35.9 \\
\hline Male & 299 & 27.7 \\
\hline Age category & 600 & 55.6 \\
\hline Less than 30 & 181 & 16.8 \\
\hline Less than 40 & 805 & 74.5 \\
\hline Less than 50 & 275 & 25.5 \\
\hline Nationality & 590 & \\
\hline Arabian & 490 & 54.6 \\
\hline Russian & & 45.4 \\
\hline Lifestyle is & 899 & 83.2 \\
\hline Luxuries & 181 & 16.8 \\
\hline Comfortable & \\
\hline The highest degree or level of school you have completed & \\
\hline Bachelor's degree & \\
\hline Master's Degree Completion & \\
\hline
\end{tabular}


Table 3 listed the characteristics of the sample, more than half of the sample was female $(64.1 \%)$ and $(35.9 \%)$ of them was male. The age of the majority of respondents was less than $40(59.8 \%)$. Arabian respondents got the highest percentage among customers (74.5\%), followed by Russian customers $(25.5 \%)$. More than half of respondents their lifestyle was luxuries $(54.6 \%)$. The highest level of education of the respondents was bachelor's (83.2\%). The results showed that female customers had a great attention to environmental issues so they were more favorable to answer the questionnaire and this matches many studies that show significant differences between men and women in environmental attitudes (Brown and Harris, 1992; Tikka, Kuitunen and Tynys, 2000) also women were more likely to buy green products because they believe the product was better for the environment (Mainieri et al., 1997). In addition, the result stated that the Arabian and younger individuals were likely to be more sensitive to environmental issues.

Table 4: Mean scores and standard deviation for hotels' green activities and customers' ethical behavior variables

\begin{tabular}{|l|c|c|}
\hline Variable & No. & $\%$ \\
\hline Hotels' green activities & 204 & 18.9 \\
\hline Low & 874 & 80.9 \\
\hline Moderate & 2 & 0.2 \\
\hline High & \multicolumn{2}{|c|}{$2.89 \pm 0.45$} \\
\hline Mean \pm SD & \multicolumn{2}{|l|}{} \\
\hline Ethical consumer behavior & 198 & 18.3 \\
\hline Low & 882 & 81.7 \\
\hline Moderate & \multicolumn{2}{|c|}{$1.82 \pm 0.77$} \\
\hline Mean \pm SD & \\
\hline
\end{tabular}

In regard of implementing green activities among hotels, Table (4) showed that $(80.9 \%)$ of respondents referred that hotels implemented green activities at moderate level with mean scores and standard deviation $(2.89 \pm 0.45)$ whereas, ethical behavior among participants was also at moderate level with (81.7) with mean score and standard deviation (1.82 \pm 0.77$)$. From the previous finding, it is noted that five-star hotels in Alexandria-Egypt do not apply green activities effectively. Thus it could be said that there was very a strong evidence to believe hypothesis one: the implementing of green activities in five -star hotels in Alexandria - Egypt is limited, as well as the ethical behavior of customers towards green hotel was not at the best.

Table 5: Descriptive analysis for sub-variables of hotels' green activities and customers' ethical behavior

\begin{tabular}{|c|l|c|c|c|}
\hline & Variables & Mean & \pm SD. & Rank \\
\hline & Hotels' green activities & & & \\
\hline A1 & Hotel uses low -flow toilets, toilets flappers, shower heads and faucet & 3.93 & 1.0 & 3 \\
\hline A2 & Hotel uses compact fluorescent or other efficient bulbs & 3.90 & 0.80 & 4 \\
\hline A3 & Hotel has a socially responsible & 1.86 & 1.18 & 11 \\
\hline A4 & Hotel use some environmental slogans and symbols in its campaigns & 2.68 & 0.88 & 6 \\
\hline
\end{tabular}


International Journal of Heritage, Tourism and Hospitality Vol. (11), No. (4), October, 2017

By: Faculty of Tourism and Hotels, Fayoum University

A Special Issue on 'Entrepreneurship of Tourism, Hospitality and Heritage in Egypt': A Vision for Sustainable Development' The $1^{\text {st }}$ International Conference Organized by Faculty of Tourism and Hotel Management, Pharos University, Alexandria, Egypt on $24^{\text {th }}-27^{\text {th }}$ October 2017

\begin{tabular}{|c|l|c|c|c|}
\hline A5 & There are posters showing hotel environmental policy & 2.52 & 1.09 & 7 \\
\hline A6 & There are awareness leaflets for guests to save energy in hotel rooms & 2.20 & 0.40 & 8 \\
\hline A7 & Recycling boxes are found in guests rooms in the bathroom & 1.50 & 0.50 & 12 \\
\hline A8 & Hotel advertises to guests the actions is to keep clean environment & 1.89 & 1.28 & 10 \\
\hline A9 & There are areas for smokers separated from non-smokers & 4.46 & 0.50 & 1 \\
\hline A10 & $\begin{array}{l}\text { Towels and linens are washed according to guest opinion to reduce } \\
\text { energy and water }\end{array}$ & 3.43 & 1.22 & 5 \\
\hline A11 & $\begin{array}{l}\text { Heating ventilating and air-conditioning system is implemented } \\
\text { efficiently to ensure making indoor environmental quality }\end{array}$ & 4.34 & 1.24 & 2 \\
\hline A12 & The hotel is successful in its environmental performance & 1.99 & 1.39 & 9 \\
\hline & Average score & 2.89 & 0.45 & \\
\hline & Total score & 34.69 & 5.37 & \\
\hline & Ethical customer behavior & & & \\
\hline B1 & I actively campaigned about an environmental / social issue & 1.13 & 0.33 & 11 \\
\hline B2 & I felt a favorable attitude toward organic food & 1.89 & 0.74 & 4 \\
\hline B3 & I had the willing to stay at a green hotel & 2.55 & 0.57 & 2 \\
\hline B4 & I recommended a hotel because of its environmental efforts & 1.27 & 0.50 & 9 \\
\hline B5 & I switched to other hotel for ecological reason & 1.86 & 0.65 & 6 \\
\hline B6 & $\begin{array}{l}\text { I have a willing to pay more for environmentally friendly hotel when } \\
\text { there were a cheaper alternatives }\end{array}$ & 2.35 & 0.94 & 3 \\
\hline B7 & I used recycling boxes during my stay in the hotel & 1.07 & 0.25 & 12 \\
\hline B8 & I used an automatic key card systemto save room energy in a hotel & 2.97 & 0.17 & 1 \\
\hline B9 & I used recyclable products during my stay in the hotel & 1.17 & 0.38 & 10 \\
\hline B10 & I boycotted a hotel because of its damage to environment & 1.80 & 0.82 & 8 \\
\hline B11 & I avoided a hotel because of its safety and hygiene scandals & 1.88 & 0.87 & 5 \\
\hline B12 & I participated in the protest event against unethical hotel & 1.82 & 0.77 & 7 \\
\hline & Average score & 1.81 & 0.22 & \\
\hline & Total score & 21.75 & 2.62 & \\
\hline
\end{tabular}

Average Mean score, "A"= 2.89, , B"= 1.81

In more clarification, the result of table (5) indicated that factors A9" There are areas for smokers separated from non-smokers, mean $=4.46 "$ and A11" Heating ventilating and airconditioning system is implemented efficiently to ensure making indoor environmental quality, mean $=4.34 "$, which meant that hoteliers cared about existing areas for smokers separated from non-smokers areas, and establishing a good ventilation system in their operations. Hoteliers showed a little attention to put posters that show hotel environmental policy( mean score for factor A6 =2.52), put environmental leaflets (Mean score for A5 = 2.20) and to engage guests in recycling program(mean score for $\mathrm{A} 7=1.50$ ); advertise the environmental actions taken by the management to customers ( mean score for $\mathrm{A} 8=1.89$ ) ; which show the weak responsibility of five- star hotels in Alexandria towards the environmental issues .

Regarding the customers' ethical behavior, the mean scores took values as follows; B8 " I used an automatic key card system to save room energy in a hotel $=2.97 "$, B3" I had the willing to stay at a green hotel, mean=2.55", B6" I have a willing to pay more for environmentally friendly hotel when there were a cheaper alternatives, mean $=2.35 "$. It was an indicator that using automatic card was the most favorable behavior done by customers, on the other hand, engaging in recycling boxes, doing actions as participating in a protest or avoiding hotels with unethical practices was low. In addition, some unfavorable behaviors among customers have 
emerged as didn't consider environmental issues in choosing their hotels and recommend a green hotel to others, moreover, customers were willing to pay more for an environmentally friendly hotel rather than joining in environmental and social issue.

Hoteliers still pay a little attention to declare environmental actions to guests and on the other part, guests still pay little interest to take part in environmental activities and joining actively in a campaign in an environmental or social issue. This result matches the study done by Blamey et al. (1999) which suggested that customers are in theory willing to pay more for a 'green' product; however, when it came to the real purchasing decision, their willingness was not matched by action. There are the inconsistencies between environmental concern and environmentally-friendly hotel purchase behavior. The "talk" is still louder than actions to some degree, on the part of consumers and hotel operations.

Table 6: Multivariate analysis linear regression for factors affecting customers' ethical behavior

\begin{tabular}{|c|c|c|c|c|}
\hline Variable & B & Beta & $\mathrm{T}$ & $\mathrm{P}$ \\
\hline A9-There are areas for smokers separated from non-smokers & 0.164 & 0.374 & $7.568^{*}$ & $<0.001^{*}$ \\
\hline $\begin{array}{l}\text { A11-Heating ventilating and air-conditioning system is } \\
\text { implemented efficiently to ensure making indoor } \\
\text { environmental quality }\end{array}$ & -0.047 & -0.270 & $6.962^{*}$ & $<0.001^{*}$ \\
\hline $\begin{array}{l}\text { A12-The hotel is successful in its environmental } \\
\text { performance }\end{array}$ & 0.066 & 0.417 & $5.179^{*}$ & $<0.001^{*}$ \\
\hline A2-Hotel uses compact fluorescent or other efficient bulbs & 0.056 & 0.206 & $2.838^{*}$ & $0.005^{*}$ \\
\hline A3-Hotel has a socially responsible & -0.026 & -0.140 & 1.781 & 0.075 \\
\hline $\begin{array}{l}\text { A8-Hotel advertises to guests the actions is to keep clean } \\
\text { environment }\end{array}$ & -0.017 & -0.100 & 1.170 & 0.242 \\
\hline A5-There are posters showing hotel environmental policy & 0.009 & 0.046 & 0.925 & 0.355 \\
\hline $\begin{array}{l}\text { A7-Recycling boxes are found in guests rooms in the } \\
\text { bathroom }\end{array}$ & 0.021 & 0.047 & 0.856 & 0.392 \\
\hline $\begin{array}{l}\text { A1-Hotel uses low -flow toilets, toilets flappers, shower } \\
\text { heads and faucet }\end{array}$ & -0.013 & -0.058 & 0.812 & 0.417 \\
\hline $\begin{array}{l}\text { A4-Hotel use some environmental slogans and symbols in its } \\
\text { campaigns }\end{array}$ & 0.014 & 0.055 & 0.770 & 0.441 \\
\hline $\begin{array}{l}\text { A6-There are awareness leaflets for guests to save energy in } \\
\text { hotel rooms }\end{array}$ & -0.011 & -0.020 & 0.321 & 0.748 \\
\hline $\begin{array}{l}\text { A10-Towels and linens are washed according to guest } \\
\text { opinion to reduce energy and water }\end{array}$ & 0.002 & 0.010 & 0.138 & 0.890 \\
\hline
\end{tabular}

F: F test (ANOVA), B: Unstandardized Coefficients, Beta: Standardized Coefficients, t: t-test of significance,

*: Statistically significant at $\mathrm{p} \leq 0.05$

Table (6) described that the hotels' green activities was significantly explained customers' ethical behavior $\left(\mathrm{R} 2=0.284, \mathrm{~F}=35.205^{*}, \mathrm{P}<0.001^{*}\right)$, thus it could be said that there was very strong evidence to believe hypothesis two: there is a significant correlation between hotels' green activities and customers' ethical behavior. The most significant factors in the model were A9" There are areas for smokers separated from non-smokers ", A11 " Heating ventilating and air-conditioning system is implemented efficiently to ensure making indoor environmental quality, and A12"The hotel is successful in its environmental performance with P-value $<0.001$. This result indicated that the implemented green activities among five-star hotels contributed to change in ethical behavior among customers with $(28.4 \%)$ and this result matched with the study done by Wang et al. (2015) which referred that customers will engage in more actual green behavior when they perceive a firm to be more "green", and that these 
perceptions will be influenced by cues of the firm's environmental efforts. This confirms the opinion of Williams and Dair (2007) that without changes to the built environment, some sustainable behavior cannot take place.

Table 7: Correlation between attitude and actual ethical behavior among customers

\begin{tabular}{|l|c|c|}
\hline \multirow{2}{*}{} & \multicolumn{2}{|c|}{ Customers attitudes } \\
\cline { 2 - 3 } & $\mathrm{r}_{\mathrm{s}}$ & $\mathrm{P}$ \\
\hline Actual ethical behavior & $-0.691^{*}$ & $<0.001^{*}$ \\
\hline
\end{tabular}

$\mathrm{r}$ : Pearson coefficient, *: Statistically significant at $\mathrm{p} \leq 0.05$

According to table (7), there is a negative significant correlation between customer attitudes (variables B2, B3, B6) and the actual ethical behavior (variables, B10, B11, B12). It is observed that there is a gap between customer attitudes and the actual ethical behavior. Although customers were willing to stay and pay more for a green hotel, their actual ethical actions as boycotted a hotel because of its damage to environment or its safety and hygiene scandals and participating in the protest event against unethical hotel were decreased, therefore, hypothesis three: there is a gap between customers' attitudes and their actual behaviors' towards a green hotel is supported in the study. Evidence of this gap is illustrated by Hughner, McDonagh, Prothero, Shultz and Stanton (2007) who showed that despite generally favorable attitudes customers hold for organic food (between 46-67\% of the population), actual buy behavior forms only (4-10)\% of different product ranges. As a result of the study by Terlau and Hirsch (2015), when it comes to the actual purchase of sustainable products, a clear inconsistency between attitudes towards sustainable consumption and actual behavior is observed. This phenomenon is called the attitude-behavior-gap. In many surveys, $30 \%$ to $50 \%$ of customers intention is to purchase sustainable products, the market share of these products is often less than $5 \%$ of the sum.

Table 8: Correlation between customers' ethical behavior with demographic profile

\begin{tabular}{|l|c|c|}
\hline \multirow{2}{*}{\multicolumn{2}{|c|}{ Characteristics of the sample }} & \multicolumn{2}{c|}{ Ethical consumer behavior } \\
\cline { 2 - 3 } & $\mathrm{r}_{\mathrm{s}}$ & $\mathrm{P}$ \\
\hline Your lifestyle & $0.486^{*}$ & $<0.001^{*}$ \\
\hline The highest degree or level of school & $0.485^{*}$ & $<0.001^{*}$ \\
\hline Gender & $0.346^{*}$ & $<0.001^{*}$ \\
\hline Age & -0.048 & 0.112 \\
\hline Nationality & $-0.280^{*}$ & $<0.001^{*}$ \\
\hline \multicolumn{2}{|l}{ rs: Spearman coefficient, *: Statistically significant at $\mathrm{p} \leq 0.05$}
\end{tabular}

The Spearman coefficient correlation in a table (8), indicated that it is statistically significant between customers' ethical behavior variables and demographic profile of the sample $\left(\mathrm{p}<0.001^{*}\right)$. This is both inline and inconsistent with Boztepe (2012) results that showed demographic characteristics (age, income education, gender and marital status) have a moderate effect on green purchase behavior. Levels of education and lifestyle of customers were the most positively correlated factors with the ethic actions; thus, introduced an evidence for accepting Hypothesis four: there is a significant correlation between the level of education of customers and their ethical behaviors.

Regarding to results of checklist table (9), about $50 \%$ of screened hotels applied for linen reuse program, only $25 \%$ of hotels had leaflets which show the hotel environmental policy $.75 \%$ of hotels provided all employees with the required training to save hotel resources and depended 
on green products in cleaning rooms and public areas. It is found that most of hotels didn't accommodate automatic faucets or toilets in public restrooms or low flow toilets, showerheads and faucets; moreover, hotels didn't involve recycle bins in their rooms; environmental label didn't existed on their products ; didn't plant a variety of fruits, herbs, and vegetables in their hotels to serve the healthiest food; didn't apply renewable energy; and finally install daylight and occupancy sensors. It is observed that most of the screened hotels at the present time didn't meet the ideal environmental activities. This result matches the study done by Brown, (1996) which believed that there are several hospitality managers who realize the impact their property is having on the environment but are limited in executing ecological practices unless there is a clear benefit as cost saving attached.

Table 9: Environmental activities undertaked by hotels

\begin{tabular}{|c|c|c|}
\hline Environmental activities matrix & YES & $\mathrm{NO}$ \\
\hline \multicolumn{3}{|l|}{ A-Environmental policy and management } \\
\hline $\begin{array}{l}\text { A1- Does the hotel provide all employees with the training and } \\
\text { resources required to meet green objectives? }\end{array}$ & $75 \%$ & $25 \%$ \\
\hline A2- Are there leaflets which show the hotel environmental policy? & $25 \%$ & $75 \%$ \\
\hline A3 -Is environmental label existed on hotels products? & $12 \%$ & $88 \%$ \\
\hline \multicolumn{3}{|l|}{ B-Measures for water reduction } \\
\hline B1- Does the hotel use a linen reuse program in guest rooms? & $50 \%$ & $50 \%$ \\
\hline B2- Does the hotel use low flow toilets, showerheads and faucets? & $10 \%$ & $90 \%$ \\
\hline B3-Does the hotel use automatic faucets or toilets in public restrooms? & $11 \%$ & $89 \%$ \\
\hline \multicolumn{3}{|l|}{ C -Waste reduction and recycling } \\
\hline $\begin{array}{l}\mathrm{C} 1 \text { Are recycling bins for glass, plastic, and paper provided in all guest } \\
\text { rooms or public area? }\end{array}$ & $2 \%$ & $98 \%$ \\
\hline C2- Does the hotel use food waste monitoring system? & $5 \%$ & $95 \%$ \\
\hline $\begin{array}{l}\text { C3- Are a variety of fruits, herbs, and vegetables grown in the hotel to } \\
\text { serve the healthiest food? }\end{array}$ & $3 \%$ & $970 \%$ \\
\hline \multicolumn{3}{|l|}{ D-Pollution control } \\
\hline $\begin{array}{l}\text { D1 -Are environmentally High-efficiency Particulate Air (HEPA) filters } \\
\text { used? }\end{array}$ & $100 \%$ & $0 \%$ \\
\hline D2- Are housekeeping environmentally products used in the hotel? & $75 \%$ & $25 \%$ \\
\hline D3- Are non-smoking rooms and smoking room existed? & $62.5 \%$ & 37.5 \\
\hline \multicolumn{3}{|l|}{ E-Measures to adopt energy reduction } \\
\hline E1- Does the hotel use on-site renewable energy? & $1 \%$ & $99 \%$ \\
\hline $\begin{array}{l}\text { E2- Does the hotel install daylight and occupancy sensors for low } \\
\text { occupancy areas? }\end{array}$ & $15 \%$ & $85 \%$ \\
\hline E 3-Does the hotel use high efficient bulbs to save energy? & $100 \%$ & $0 \%$ \\
\hline
\end{tabular}

\section{Conclusion and implication}

Ethical tourism is as a concept when a person considers making a journey to or developing tourism in a destination where ethical issues are the main triggers. Ethical tourism is towards encouraging both the consumer and industry to keep away from sharing in activities that support negative ethical issues (Lovelock and Lovelock, 2013). The current research moves beyond the earlier studies on the influence of green activities in hotels on ethical actions among customers. This study succeeded in showing that there is a positive relationship between implemented green activities and ethical actions of customers. The obtained data suggesting 
respondents' impassiveness towards ecological behavior and waste recycling process appears alarming since this can be a source of a large amount of savings. Hoteliers should look for ways to motivate customers to engage more in green activities as setting a loyalty program. Hoteliers should give more attention to existing a written environmental policy, moreover, using an environmental slogan on all hotels products and on their, planting organic food and setting up an effective recycling program. The necessity of evaluation system includes a full range environmental impacts for a hotel (materials, products, and services involved), In addition to existing a system for following-up energy consumption through periodic reports for all hotel activities. The role of hotels should be extended to reach to the community through raising ethical behavior level among consumers and increase community participation to stand towards hotels that implement policies that may harm the environment, thus will improve ethical behavior in a whole society.

\section{Recommendation and further study}

The ministry of tourism should encourage hotels to cooperate with international conservation organizations which aim to preserve the environment by establishing sustainable projects which help decrease the negative impact on the environment. Attention should be given to increase awareness of dangerous of low ethical behavior in the society and setting cultural programs for employees and consumers. Future studies should attempt to incorporate ways of motivating consumers for ethical behavior as conservation behavior and the reactance of consumers against. Further studies are necessary to identify the reasons behind a gap between attitude and actual behavior among consumers. Also, future studies should take into account the effect of consumers' nationalities and the level of culture of ethical consumer behavior.

\section{References}

Attila, A.(2016).The Impact of the Hotel Industry on the Competitiveness of Tourism Destinations in Hungary. Journal of Competitiveness, Vol. 8, Issue 4, PP. 85- 104.

Bardi, A. (2010). Hotel Front Office Management. Hoboken, New Jersey, US. John Wiley and Sons.

Bohdanowizs ,P.(2005).European Hoteliers Environmental Attitudes :Greening the Business. Cornell Hotel and Restaurant Administration Quarterly,46,188-204.

Boztepe A. Green marketing and its Impact on Consumer Buying Behavior. European Journal of Economic and Political Studies. 2012;5(1):5-21.

Bohdanowicz, P. (2006). Environmental Awareness and Initiative in the Swedish and Polish Hotel Industries-Survey Results. International Journal of Hospitality Management, 25, 662-682.

Brinkmann ,J.( 2003). Looking at Consumer Behavior in a Moral Perspective", The Journal of Business Ethics, Niagara University,NY.,Oct.23-25,P.26.

Brown, M. (1996) "Environmental policy in the hotel sector; "green" strategy or stratagem?" International Journal of Contemporary Management, Volume 8, Number, 3, p.18-23.

Carayannis ,E.(2013) .Creating a Sustainable Social Ecology Using Technology-driven Solutions. Idea Group Inc (IGI),USA.,P.102.

Cherrier, H. (2006). Consumer Identity and moral obligations in non-plastic bag consumption: A dialectical perspective. International Journal of Consumer Studies, 30, 515-523.

Cherrier, H. (2007). Ethical Consumption Practices: Co-Production of Self-Expression and Social Recognition, Journal of Consumer Behaviour, Vol. 6, PP. 321-335.

Cialdini , R. (2009). Influence: Science and Practice. Fifth Edition, Boston, Allyn \& Bacon. 
International Journal of Heritage, Tourism and Hospitality Vol. (11), No. (4), October, 2017

By: Faculty of Tourism and Hotels, Fayoum University

A Special Issue on 'Entrepreneurship of Tourism, Hospitality and Heritage in Egypt': A Vision for Sustainable Development'

The $1^{\text {st }}$ International Conference Organized by Faculty of Tourism and Hotel Management, Pharos University, Alexandria, Egypt on $24^{\text {th }}-27^{\text {th }}$ October 2017

El Kadhi, W. (2009). Cross-Cultural Destination Image Assessment: Cultural Segmentation Versus the Global Tourist: An Exploratory Study of Arab-Islamic and Protestant European Youths' Pre-visitation Image on Berlin. Diplomica Verlag, Hamburg, p. 71.

Ellis, J. (2010). Energy Service Companies (ESCOs) in Developing Countries. Manitoba, Canada, International Institute for Sustainable Development.

Forte, J. (2003) .Environmental-Friendly Management in Hotels. In Taylor, B. et al (eds), Environmental Management Handbook, Pitman Publishing, London, pp. 97-113.

Gronhoj, A. (2006). Communication about Consumption: A Family Process Perspective on "Green" Consumer Practices. Journal of Consumer Behavior, Vol. 5, PP. 491-503.

Gursoy, D.(2018). Rutledge Handbook of Hospitality Marketing. Business \& Economics, Rout ledge ,New York.

Keller ,P.(1996) .Tourism and Environment: Towards a New Tourist Culture. Council of Europe, November ,21-23,No.36.,Switzland ,P.20.

Kirk, D. (1996). Environmental Management for Hotels: A Student's Handbook. ButterworthHeinemann ,Oxford, UK.

Kirkpatrick, L. (2013). A Simple Guide to IBM SPSS Statistics for Version 20.0.Twelfth Edition, Belmont, CA. ,Wadsworth Cengage Learning.

Lefevre , J.(2012). Biodiversity: My Hotel in Action: a Guide to Sustainable Use of Biological Resources in the Caribbean. International Union for Conservation of Nature and Natural Resources, Switzland, p.19

Lubbe, A.(2003). Tourism Management in Southern Africa, Pearson South Africa. Department of Tourism and Management, University of Pretoria, Pearson education south Africa, ,p.77.

Ly, T. (2013). Measuring The Perceived Destination Image of Vietnam in Finland. Tourism Research, University of Lapland, Faculty of Social Sciences, Finland, p. 55.

Makeower, J. (2009). Strategies for the Green Economy: Opportunities and Challenges in the New World of Business. New York: McGraw-Hill.

Manhas ,P.(2012).Sustainable and Responsible Tourism: Trends, Practices and Cases. Phi Learning Pvt. Ltd .,New Delhi ,p.86.

McCabe,S.(2009) .Marketing Communications in Tourism and Hospitality. Elsevier ,Oxford,P.2.

Miththapala , S. (2011).Good Practice Guidelines on Environmental Management for Sri Lankan hoteliers. SWITCH Asia Greening Sri Lanka Hotels Project, Colombo.

Mensah, I. (2006). Environmental Management Practices among Hotels in the Greater Accra region. International Journal of Hospitality Management, 25, 414-431.

Pattie,K.(1995). Environmental Marketing Management : Meeting the Green Challenge. Division of Pearson Professional Limited, London,P.80

Pearce, D. (1994). Sustainable Consumption through Economic Instruments. Paper Prepared for the Government of Norway Symposium on Sustainable Consumption, Oslo, 19-20 January.

Schwartz,D.(2017). Consuming Choices : Ethics in a Global Consumer Age. Rowman \& Littlefield London ,p.4.

Shanti ,J.(2016). A Study on Environmental Sustainability Practices of Star Hotels in Bangalore, Asian J Bus Ethics . Springer Science Business Media Dordrecht, 5,PP. 185-194.

Townsend ,A. (2009).Business Ecology : why most green business practices don't work and what to do about it. Schiffer Pub. Limited,USA.,P.27.

Webster, K. (2000). Environmental Management in the Hospitality Industry: A Guide for Students and managers, London, Cassell .

Weeden, C.( 2002). Ethical Tourism: An Opportunity for Competitive Advantage? Journal of Vacation Marketing, Vol.8, No.2,PP. 141-153. 
International Journal of Heritage, Tourism and Hospitality Vol. (11), No. (4), October, 2017

By: Faculty of Tourism and Hotels, Fayoum University

A Special Issue on 'Entrepreneurship of Tourism, Hospitality and Heritage in Egypt': A Vision for Sustainable Development'

The $1^{\text {st }}$ International Conference Organized by Faculty of Tourism and Hotel Management, Pharos University, Alexandria, Egypt on $24^{\text {th }}-27^{\text {th }}$ October 2017

Wickramasinghe ,K. (2016) . Adoption of Environmental Management Practices in the Hotel Industry in Sri Lanka. South Asian Network for Development and Environmental Economics (SANDEE), Nepal,p.1

Zemake, D.(2014). Managing the Built Environment in Hospitality Facilities: Business . First Edition ,Content technologies, Inc.

Zhou, M.(2011). Advances in Education and Management: International Symposium. Springer-Verlage Berlin Heidelberg, London ,P.241.

Alexander, S. and Kennedy, C. (2002). Green Hotels: Opportunities and Resources for Success. Zero Waste Alliance, 5(7),PP.1-9.

Ali, A. and Frew ,A. (2013).Information and Communication Technologies for Sustainable Tourism. Rutledge ,Canada,P.81.

Bhate, S. and Lawler, K. (1997). Environmentally Friendly Products: Factors that Influence their Adoption. Technovation , 17, PP .457-465.

Brown, G. and Haris, C. (1992). The US forest service: Toward the new resource management paradigm? Society and Natural Resources, 5, 231-245.

Carrier, J., and Luetchford, P.(2012). Ethical Consumption: Social Value and Economic Practice . Berghabn , New york,P.2

Graci, S. and Dodds, R. (2008). Why go green? The business Case for Environmental Commitment in the Canadian Hotel Industry. Anatolia, 19(2), 251-270.

Crane,A. and Matten, D.(2004).Business Ethic, a European Perspective Managing Corporate

Citizen and Sustainability in the age of Globalization. Oxford, Oxford University Press.

Delistavrou , A. and Tilikidou ,I. (2014). Ethical Consumer Behaviour Regarding Hotels: Types and Influential Factors, International Conference on Contemporary Marketing Issues (ICCMI) (2014: Athens, Greece),PP. 467-472.

Díaz ,M. and Rodríguez, T.(2016). Determining the Sustainability Factors and Performance of Tourism Destination from the Stakeholders Perspective. Department of Business and Management, Universidad de Las Palmas de Gran Canaria ,Spain .

Firat, F. and Dholakia, N. (2003). Consuming People: From Political Economy to Theaters of Consumption. London, England: Routledge,P.2.

Goodwin, H. and Francis, J. (2003).Ethical and Responsible Tourism: Consumer Trends in the UK. Journal of Vacation Marketing, Vol. 9, No. 3, pp. 271-284.

Han, H. and Yoon ,H.(2015) . Hotel Customers' Environmentally Responsible Behavioral Intention: Impact of Key Constructs on Decision in Green Consumerism. International Journal of Hospitality Management, 45: 22-33.

Hansen, S. and Brown, J. (2003).Investment Grade Energy Audit. Fairmont Press, New York, p.110.

Juvan, E. \& Dolnicar, S. (2014) The Attitude-Behaviour Gap in Sustainable Tourism. Annals of Tourism Research, 48:76-95.

Lewis,T. and Potter ,E.(2013)," Ethical Consumption: A Critical Introduction" Taylor and Francis group ,London,p.6.

Lovelock, B. and Lovelock ,K.(2013).The Ethics of Tourism: Critical and Applied Perspectives. Routledg.e ,Canada,p.5

Maltzman ,R. and Shirley ,D.(2011). Green project management . CRC Press, Boca Raton.PP.18,34.

Manaktola , K. and Jauhari, V. (2007).Exploring Consumer Attitude and Behavior towards Green Practices in the Lodging Industry in India. International Journal of Contemporary Hospitality Management, Vol. 19, No. 5, pp. 364-377.

Millar, M. and Baloglu, S. (2008). Hotel Guests' Preferences for Green Hotel Attributes. Proceedings of the European Council for Hotel, Restaurant, and Institutional Education Conference, Dubai, United Arab Emirates. 
International Journal of Heritage, Tourism and Hospitality Vol. (11), No. (4), October, 2017

By: Faculty of Tourism and Hotels, Fayoum University

A Special Issue on 'Entrepreneurship of Tourism, Hospitality and Heritage in Egypt': A Vision for Sustainable Development'

The $1^{\text {st }}$ International Conference Organized by Faculty of Tourism and Hotel Management, Pharos University, Alexandria, Egypt on $24^{\text {th }}-27^{\text {th }}$ October 2017

Newholm, T. and Shaw, D. (2007). Studying the Ethical Consumer: a Review of Research. Journal of Consumer Behaviour, Vol.6, PP. 253-270.

Quintana ,T. and Canino ,R.(2017). Successful Case Studies in the Canary Islands' Tourism Industry.Cambridge Scholars Publishing, UK,P.131.

Shaw, D. and Clarke, I. (1999). Belief Formation in Ethical Consumer Groups: An Exploratory Study, Marketing Intelligence and Planning, 17, PP.109-119.

Shaw, D. and Shiu, E. (2003). Ethics in Consumer Choice: A Multivariate Modeling Approach. European Journal of Marketing, 37(1), 1485-1498.

Shaw, D. and Newholm, T. (2002). Voluntary Simplicity and the Ethics of Consumption. Psychology and Marketing , Vol.19, PP.167-185.

Swami, R. and Sharma ,S.(2011).Hotel industry embraces "Green Revolution" across the globe. International Transactions in Applied Sciences, Volume 3, No. 3, PP. 363-380.

Terlau ,W. and Hirsch,D. (2015). Sustainable Consumption and the Attitude-Behaviour-Gap Phenomenon -Causes and Measurements towards a Sustainable Development. International Centre for Sustainable Development - IZNE -, Bonn-Rhein-Sieg University of Applied Sciences, Gemany,P. 160.

Tilikidou, I. and Delistavrou, A. (2011). Which Unethical Hotel Practices Cause Consumers' Boycotts? Proceedings of the 3rd International Conference Special Interest Tourism \& Destination Management, 27-30 April, PP. 271-278.

Weeden ,C. and Boluk ,K.( 2014) . Managing Ethical Consumption in Tourism. Rutledge ,New York.

Williams, K. and Dair C. (2007). A Framework of Sustainable Behaviours that can be Enabled through the Design of Neighborhood-Scale Developments. Sustainable Development Vol .15, PP.160-173.

Barberán , P . ; Gracia-de-Rentería, E. and Salvador,M. (2013). Evaluation of water saving measures in hotels: A Spanish case study. International Journal of Hospitality Management ,34,PP. 181-191.

Baker, A.; Davis, A., and Weaver, A. (2014).Eco-friendly Attitudes, Barriers to Participation, and Differences in Behavior at Green Hotels. Cornell Hospitality Quarterly, Vol. 55 No. 1, PP. 89-99.

Blamey, R., Bennett, J., Louviere, J. and Morrison, M. (1999). Validation of a Choice Model Involving Green Product Choice, Choice Modeling Research Report No.10. Sydney, The University of New South Wales.

Boemi, N.; Avdimiotis, S. and Fotiadou, K. (2013). Sustainability Assessment in Tourist Facilities. International Conference on Tourism (ICOT) proceedings, 2012, Archanes Crete, May 22-26, 2012.

Botero,C. Cervantes,O. Finkl ,C.(2018). Beach Management Tools - Concepts, Methodologies and Case Studies, Costal research library 24 , Springer international publishing ,p.23

Carrington, J.; Neville, A. and Whitwell, J. (2014). Lost in Translation: Exploring the Ethical Consumer Intention-Behavior Gap. Journal of Business Research, 67, 2759-2767.

Chen,J.; Sloan,P. and Legrand,W.(2009).Sustainability in the Hospitality Industry . Butterworth Heinemann,London,p.1

De Pelsmacker, P.; Driesen, L. and Rayp, G. (2005). Do Consumers Care about Ethics? Willingness to pay for fair Trade Coffee . Journal of Consumer Affairs, 39(2), PP. 363-385.

Devinney,T. ;Auger, P., and Eckhardt ,G.(2010). The Myth of the Ethical Consumer Hardback with DVD. Cambridge University Press,P.1.

Diamantopoulos, A. ; Schlegelmilch, B., Sinkovics, R. and Bohlen, G. (2003). Can socio-Demographics Still Play a Role in Profiling Green Consumers? A review of the Evidence and an Empirical Investigation. Journal of Business Research, 56, PP.465-480. 
International Journal of Heritage, Tourism and Hospitality Vol. (11), No. (4), October, 2017

By: Faculty of Tourism and Hotels, Fayoum University

A Special Issue on 'Entrepreneurship of Tourism, Hospitality and Heritage in Egypt': A Vision for Sustainable Development'

The $1^{\text {st }}$ International Conference Organized by Faculty of Tourism and Hotel Management, Pharos University, Alexandria, Egypt on $24^{\text {th }}-27^{\text {th }}$ October 2017

Dub ,L .; Enz ,C., Renaghan , L. and Siguaw,J.(1999). Best Practices In United States Lodging Industry :Overview ,Methods, and The Champions .Cornell Hotel and Restaurant Adminstration ,Qurtely,Vol,40,No.4,PP.14-27.

Fisher, C. ; Bashyal, S. and Bachman, B. (2012). Demographic Impacts on Environmentally Friendly Purchase Behaviors. Journal of Targeting, Measurement and Analysis for Marketing, 20(3),PP. 172-184. http://dx.doi.org/10.1057/jt.2012.13.

Han, H.; Hsu , T. and Sheu, C. (2010). Application of the Theory of Planned Behavior to Green Hotel Choice: Testing the Effect of Environmental Friendly Activities, Tourism Management, Vol. 31. PP. 325-334.

Han, H.; Hsu, J., Lee, J. and Sheu, C. (2011).Are Lodging Customers Ready to Go Green? An Examination of Attitudes, Demographics, and Eco-friendly Intentions. International Journal of Hospitality Management, 30(2), 345-355.

Harrison, R. ; Newholm, T. and Shaw, D. (2005). The Ethical Consumer. London, England: Sage Publication Ltd., PP.2-4.

Hughner S. ; McDonagh P., Prothero, A. , Shultz J. and Stanton J. (2007). Who are Organic Food Consumers? A Compilation and Review of Why People Purchase Organic Food, Journal of Consumer Behaviour, Vol.6, PP. 94-110.

Mainieri, T. ; Barnett, E., Valdero, T., Unipan, J. and Oskamp, S. (1997). Green buying: The influence of environmental concern on consumer behavior. Journal of Social Psychology, 137, 189-204.

Micheletti, M.; Stolle, D., Nishikawa, L. and Wright, M. (2005). A Case of Discursive Political Consumerism: The Nike E-mail Exchange. The 2nd International Seminar Proceedings, Oslo, Norway, PP. 255-290.

Monette, D., Sullivan, T. and DeJong, C. (2011). Applied Social Research: A Tool for the Human Services. Eighth Edition, Cengage Learning, United States, p. 4.

Ofori, G.; Savage V. and Lin-heng ,L.(2010).Sustainability Matters: Environmental Management In Asia. World Scientific publishing Co. ,Pte.Ltd.,P.33.

Ozcaglar-Toulouse, N.; Shiu, E. and Shaw, D. (2006). In search of fair trade: Ethical consumer decision making in France, International Journal of Consumer Studies, Vol.30, PP.502-514.

Quoquab , F.; Thurasamy , R. and Mohammad , J.(2018). Driving Green Consumerism Through Strategic Sustainability Marketing. IGI Global ,United States ,p.6.

Rahman, I.; Reynolds, D. and Svaren, S. (2012). How "Green" are North American hotels? An Exploration of Low-cost Adoption Practices. International Journal of Hospitality Management, 31(3), 720-727.

Smith , A. ; Choy,V., Chong ,H. and Verma ,R.(2015). Environmental Sustainability in the Hospitality : Best Practices ,Guest Participation and Customer Satisfaction ,Cornell hospitality Report ,15(3),6-16.

Tallontire, A.; Rentsendorj, E. and Bowfield, M., (2001) . Ethical Consumers and Ethical Trade: A Review of Current Literature( Policy Series 12). Natural Resources Institute, Chatham, UK.

Thorne, D.; Ferrell ,O. and Ferrell, L.(2011). Business \& Society : A Strategic Approach to Social Responsibility and Ethics. Fourth Edition, South Western, Cengage Learning ,United States ,P.430.

Tikka, M., Kuitunen, T., and Tynys, M. (2000). Effects of Educational Background on Students' Attitudes, Activity Levels, and Knowledge Concerning the Environment. The Journal of Environmental Education, 31, 12-19.

Tilikidou, I. ; Delistavrou, A. and Sapountzis, N. (2013). Customers' Ethical Behaviour towards

Hotels paper presented, the 5th International Conference, The Economies of Balkan and 
International Journal of Heritage, Tourism and Hospitality Vol. (11), No. (4), October, 2017

By: Faculty of Tourism and Hotels, Fayoum University

A Special Issue on 'Entrepreneurship of Tourism, Hospitality and Heritage in Egypt': A Vision for Sustainable Development'

The $1^{\text {st }}$ International Conference Organized by Faculty of Tourism and Hotel Management, Pharos University, Alexandria, Egypt on $24^{\text {th }}-27^{\text {th }}$ October 2017

Eastern Europe Countries in the changed world" - EBEEC 2013, Istanbul, Turkey ProcediaEconomics and Finance, Vol. 9, pp. $425-432$.

Tzschentke, A., Kirk, D. and Lynch, A. (2008). Going green: Decisional Factors inSmall Hospitality Operations. International Journal of Hospitality Management, 27, 126-133.

Wagner, T. ; Richard L. and Barton W.(2009). Corporate Hypocrisy: Overcoming the Threat of Inconsistent Corporate Social Responsibility Perceptions. Journal of Marketing, 73(6), 77-91.

Wang ,W.; Krishna ,A. and Mcferran ,B.(2015). Turning Off The Lights: Consumers' Environmental Efforts Depend On Visible Efforts Of Firms, Ap - Asia-Pacific, Advances Consumer Research .Volume 11, Eds. Echo Wen Wan and Meng Zhang, Duluth, Mn : Association For Consumer Research, PP. 197-201.

William, H. ; Batchelder,W. and Narens,I. (1977). A Critical Examination of the Analysis of Dichotomous Data, University of California, Irvirte,P.116.

Zengeni,N.; Zengeni ,D. and Muzambi,S.(2013). Hoteliers Perceptions of the Impacts of Green Tourism on Hotel Operating Cost in Zimbabwe: The Case of Selected Harare Hotels . Australian Journal of Business and Management Research ,2(11),64-73.

Do Paço, A. and Raposo, M. (2009). Green" Segmentation: An Application to the Portuguese Consumer Market. Marketing Intelligence \& Planning, 27(3), PP.364-379. Available at: http://dx.doi.org/10.1108/02634500910955245

Ethical Consumer Markets Report (2012). The Co-Operative. Available at: http://www. ethical consumer. Org/portals/0/downloads/ethical-consumer-markets-report-2012. [Accessed 26 August 2014].

Follows, B. and Jobber, D. (2000). Environmentally Responsible Purchase Behaviour: a Test of a Consumer Model. European Journal of Marketing, 34(5/6), PP. 723-746. Available at :http://dx.doi.org/10.1108/03090560010322009.

Green Hotelier,(2003). Beyond the Nile Valley to the Red Sea Coast. Available at: http://www.greenhotelier.org. Accessed [7th June 2018].

Green Hotels Association, (2005). What is a Green Hotel? Available at: http://greenhotels.com/ index.php. Accessed [12th January 2011].

Green Lodging News (2008). Retrieved January 31, Available at : http://www. greenlodgingnews.com.

Holcomb, L.; Upchurch, S. and Okumus, F. (2007). Corporate Social Responsibility: What are Top Hotel Companies Reporting . International Journal of Contemporary Hospitality Management, 19 (6), 461- 475. Available at: http://dx.doi.org.

Keynote (2002). The Green and Ethical Consumer. Available at : www.keynote.co.uk

Wenger, A. (2010). Communities of practice. Available at : www. ewenger.com/food.

William, D. and Frye,P. (2009). Cost-Saving Tips for Tough Times. Available at : http://lhonline.com. 